\title{
Potential of bacteria in sheep feces as biogas formation starter on lignite coal media
}

\author{
Hidayati $\mathrm{YA}^{\left.1^{*}\right)}$, Marlina $\mathrm{ET}^{1)}$, Rahmah $\mathrm{KN}^{1)}$, Pinandito $\mathrm{K}^{1)}$, Puteri $\mathrm{GCK}^{1)}$ and Harlia $\mathrm{E}^{1)}$ \\ ${ }^{1)}$ Faculty of Animal Husbandry, Universitas Padjadjaran, Sumedang, Indonesia, 45363
}

Submitted: 21 October 2019, Accepted: 21 November 2020

\begin{abstract}
Sheep farms produce waste in the form of feces and urine that are organic materials and the source of bacteria. This study aims to determine the potential of bacteria in sheep feces when used as a starter for biogas formation (the number of anaerobic bacteria and biogas production) on lignite coal media. The method used in this study was experimental in the laboratory using a completely randomized design with four treatments and four replications. The data were analyzed using analysis of variance, and Duncan test was performed to find out the differences between treatments. The research procedure was divided into two stages. The first stage was in vitro method to select the feces sample with the largest biogas production. The second stage was utilizing enriched media (media 98-5) liquid for observing the growth of bacteria originating from selected sheep feces, and then the bacteria consortium was used as starters on lignite coal media. The treatments were based on the concentration of bacteria consortium used, $\mathrm{T} 1=0 \%, \mathrm{~T} 2=1.5 \%, \mathrm{~T} 3=3 \%$, and $\mathrm{T} 4=4.5 \%$. The number of anaerobic bacteria was observed in Hungate tubes, and biogas production was observed in serum bottles. The results showed that the highest number of anaerobic bacteria $\left(10^{12} \mathrm{CFU} / \mathrm{ml}\right)$ and the highest biogas production $(105 \mathrm{~mL})$ were achieved at $\mathrm{T} 2=1.5 \%$. Bacteria in sheep feces can be potentially used as a biogas forming agent on lignite coal media, which is proved by the growth of anaerobic bacteria and the biogas production from present study.
\end{abstract}

Keywords: Sheep feces; Lignite coal; Anaerobic bacteria; Biogas

\footnotetext{
*Corresponding Author: yuli.astuti@unpad.ac.id
} 


\section{INTRODUCTION}

Indonesia is a tropical country where forages grow throughout the year. In the dry season, forage crop production decreases, while in the rainy season, the production of forage crops is abundant. Forage crops in the rainy season can be preserved into silage for forage supplies in the dry season. The by-product of sheep farms is feces, which is an organic waste. The content of anaerobic bacteria in feces is influenced by the feed intake (Ayuningtyas et al., 2018). Based on this, the potential content of anaerobic bacteria from sheep fed Napier grass (Pennisetum purpureum) and sheep fed silage and concentrates should be examined. Then the bacteria are used as starters in the formation of biogas.

The biogas formation can be divided into four stages. The hydrolysis stage, which is the stage of decomposition of organic matter into simpler materials and that carried out by the aerobic bacteria. The second stage is acidogenesis, where the hydrolysis products are converted into small organic acids. In the acetogenic stage, organic acids are formed by facultative anaerobic bacteria. The last stage is methanogenic, the stage of biogas formation (Lohani and Havukainen, 2018). The main gas needed in biogas is methane $\left(\mathrm{CH}_{4}\right)$, which is a source of energy. However, the composition of biogas includes several gases such as methane $\left(\mathrm{CH}_{4}\right) 50-80 \%$, carbon dioxide $\left(\mathrm{CO}_{2}\right) 20$ $50 \%$, hydrogen $\left(\mathrm{H}_{2}\right) 1-5 \%$, nitrogen $\left(\mathrm{N}_{2}\right) 0$ $-0.3 \%$, oxygen $\left(\mathrm{O}_{2}\right) 0.1-0.5 \%$ and a little hydrogen sulfide $\left(\mathrm{H}_{2} \mathrm{~S}\right)$, which forms each of these gases follow the patterns and stages in the process of forming biogas (Marlina, 2009). The quality and quantity of biogas production are influenced by several factors, i.e., the substrate as organic material, particle size, anaerobic bacteria content, temperature, acidity, moisture content formation (Lohani and Havukainen, 2018). Zuriana (2017) stated that water content affects the fermentation process, and Beauchemin (2003) states that straw cutting will affect the rumen's fermentation process. Hidayati (2018) stated that anaerobic bacteria's growth is influenced by the number of inoculum and available media. Besides, Fayyaz (2014) stated that biogas production is very dependent on the number of inoculums of anaerobic bacteria and organic material to be degraded. Marlina (2018) reported that methane production was directly proportional to the growth of anaerobic bacteria. In particular, the anaerobic bacteria consortium isolated from beef cattle feces can be used as a starter to improve biogas production (Hidayati, 2018). Vinay (2018) stated that geological history, particularly the plants and vegetations' thermal influence and time, divided coal into several ranks, i.e., peat, lignite, bituminous, anthracite.

Lignite coal is the youngest coals and contains $25-30 \%$ organic carbon, so it can be used as organic material, which will be degraded in the formation of biogas. In the process of coal formation, there is methane gas called coal bed methane (CBM). In order to optimize CBM in coal, it is necessary to add bacterial inoculum as a starter. Tianyu (2018) states that subbituminous coal is oxidized with hydrogen peroxide $\left(\mathrm{H}_{2} \mathrm{O}_{2}\right)$ can produce biomethane. Based on this, research on adding starters in lignite coal to produce biogas is essential. This study aims to determine the potential of bacteria in sheep feces used as a starter for biogas formation in lignite coal media, with parameters observed the number of anaerobic bacteria and biogas production.

\section{MATERIALS AND METHODS Materials}

The materials used in this research were sheep feces, lignite coal, sheep rumen fluid, and media consisting of mineral solutions I $\left(\mathrm{K}_{2} \mathrm{HPO}_{4}\right.$, distilled water $)$; mineral solutions II $\left[\mathrm{NaCl},\left(\mathrm{NH}_{4}\right) 2 \mathrm{SO}_{4}\right.$, $\mathrm{KH}_{2} \mathrm{PO}_{4}, \mathrm{CaCl}_{2}, \quad \mathrm{MgSO}_{4} .7 \mathrm{H}_{2} \mathrm{O}$, distilled water; diluent solution $\left(\mathrm{Na}_{2} \mathrm{CO}_{3}\right.$, cysteine$\mathrm{HCl} . \mathrm{H}_{2} \mathrm{O}$, resazurin solution $0,1 \%$, distilled 
water); media 98-5 (Ogimoto and Imai, 1980) [ mineral solutions I, mineral solutions II, Resazurin $0,1 \%$, distilled water, Bacto-agar] and starch soluble, rumen fluid, glucose, cellobiose, cysteine$\mathrm{HCl} . \mathrm{H}_{2} \mathrm{O}, \mathrm{NaCO}_{3} 8 \%$; buffer solution $\left(\mathrm{NaHCO}_{3}, \quad \mathrm{Na}_{2} \mathrm{HPO}_{4}, \quad \mathrm{KCl}, \quad \mathrm{NaCl}\right.$, $\mathrm{MgSO}_{4} .7 \mathrm{H}_{2} \mathrm{O}, \mathrm{CaCl}_{2} .2 \mathrm{H}_{2} \mathrm{O}$, distilled water)

\section{Methods}

This study was divided into two stages; the first stage is starter preparation through the in vitro method; the second stage was the starter application on lignite coal media.

\section{Starter preparation}

Feces samples from sheep fed grass (Pennisetum purpureum) and sheep fed silage and concentrate, in the form of whole and mashed were collected. The potential tested for producing biogas was performed using the in vitro method, then the feces that produced the highest biogas amount, was used as source of starter.

\section{Research procedure}

The starter was inoculated on $98-5$ liquid media, incubated at $39^{\circ} \mathrm{C}$ for 14 days for the adaptation process. The serum bottles filled with coal and 98-5 liquid media were prepared. Then the starter was added according to the treatment dose, i.e., $\mathrm{T} 1=0 \%, \mathrm{~T} 2=1.5 \%, \mathrm{~T} 3=3 \%$, and $\mathrm{T} 4=$ $4.5 \%$, then incubated for $60 \mathrm{~d}$. Variables observed were the number of anaerobic bacteria, biogas production, and $\mathrm{CH}_{4}$ levels. The number of anaerobic bacteria was measured using 98-5 solid media in a Hungate tube.

The method used in this study was experimental in the laboratory using a completely randomized design with four treatments and four replications. The data obtained were analyzed using analysis of variance (ANOVA) and Duncan test was performed to find out the differences between treatments.

\section{RESULT AND DISCUSSION Potential of sheep faeces in producing biogas.}

The results of biogas production using the in vitro method of sheep feces fed with grass (Pennisetum purpureum) and sheep fed silage and concentrates, in whole, and mashed form are presented in Fig. 1. The results of analysis of variance and the Duncan test can be seen in Table 1 .

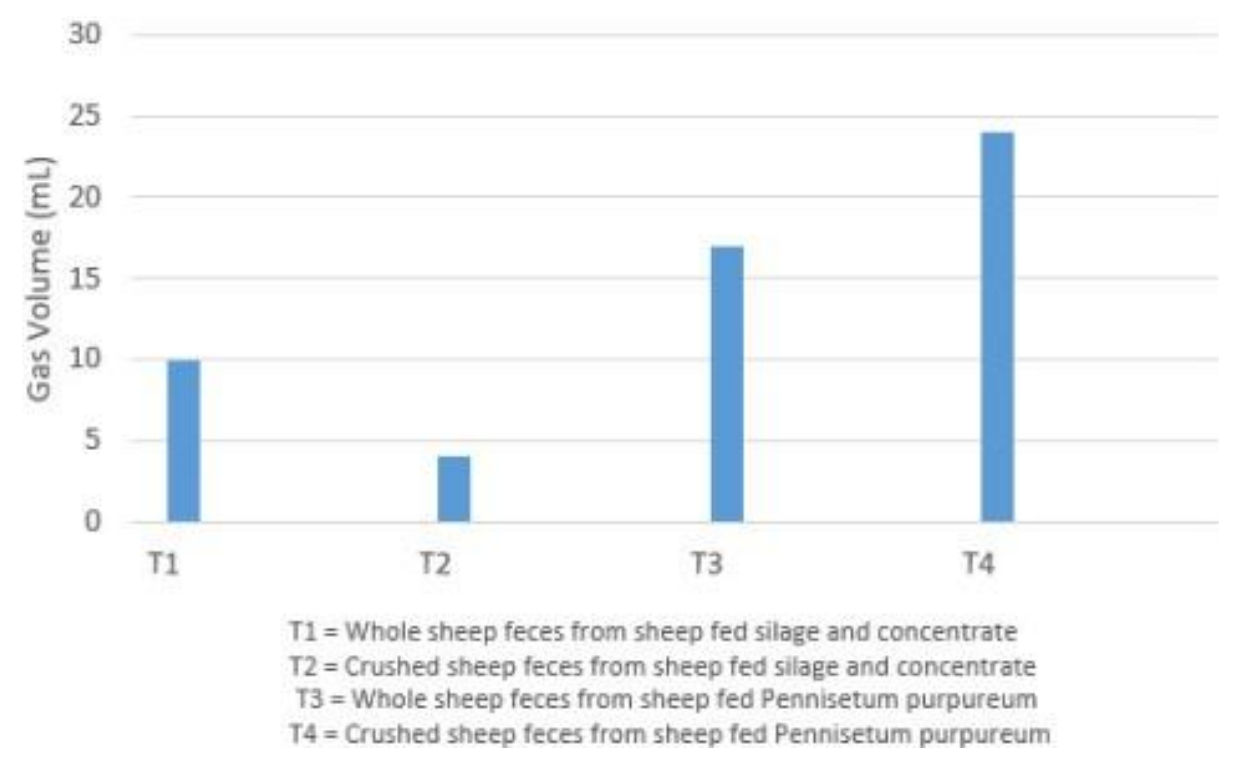

Figure 1. In vitro biogas production 
Table 1. The results of the analysis of variance and the Duncan test

\begin{tabular}{|c|c|c|}
\hline Treatment & Average Biogas Production & Significance $(0.05)$ \\
\hline $\mathrm{T} 4$ & $24,000 \pm 0.3082$ & 0 - \\
\hline T3 & $17,000 \pm 0.3162$ & $\mathrm{~b}$ \\
\hline $\mathrm{T} 1$ & $10,000 \pm 0.3082$ & $\mathrm{c}$ \\
\hline $\mathrm{T} 2$ & $4,000 \pm 0.2550$ & $\mathrm{~d}$ \\
\hline
\end{tabular}

Description: The same letter in the direction of the column indicates not significantly different and which different letter direction of the column shows significantly different effects.

The analysis of variance showed differences between treatments. The observations show that $\mathrm{T} 4$ produced the highest gas volume. T4 included sheep feces' treatment, which was crushed and obtained from sheep fed with Pennisetum purpureum. This was thought to affect the volume of gas produced. When sheep fed fresh forage, the feces contained much water, and the treatment of crushed feces expanded the surface as a result in vitro fermentation process would produce more gas. This is in line with Purnomo A (2017), which states that water content affects the fermentation process, and Beauchemin (2003) opinion states that straw cutting will affect the fermentation process in the rumen.

\section{Effect of addition of starter on lignite coal on total anaerobic bacteria}

The study results of the effect of adding starters to lignite coal on the number of anaerobic bacteria are presented in Fig. 2.

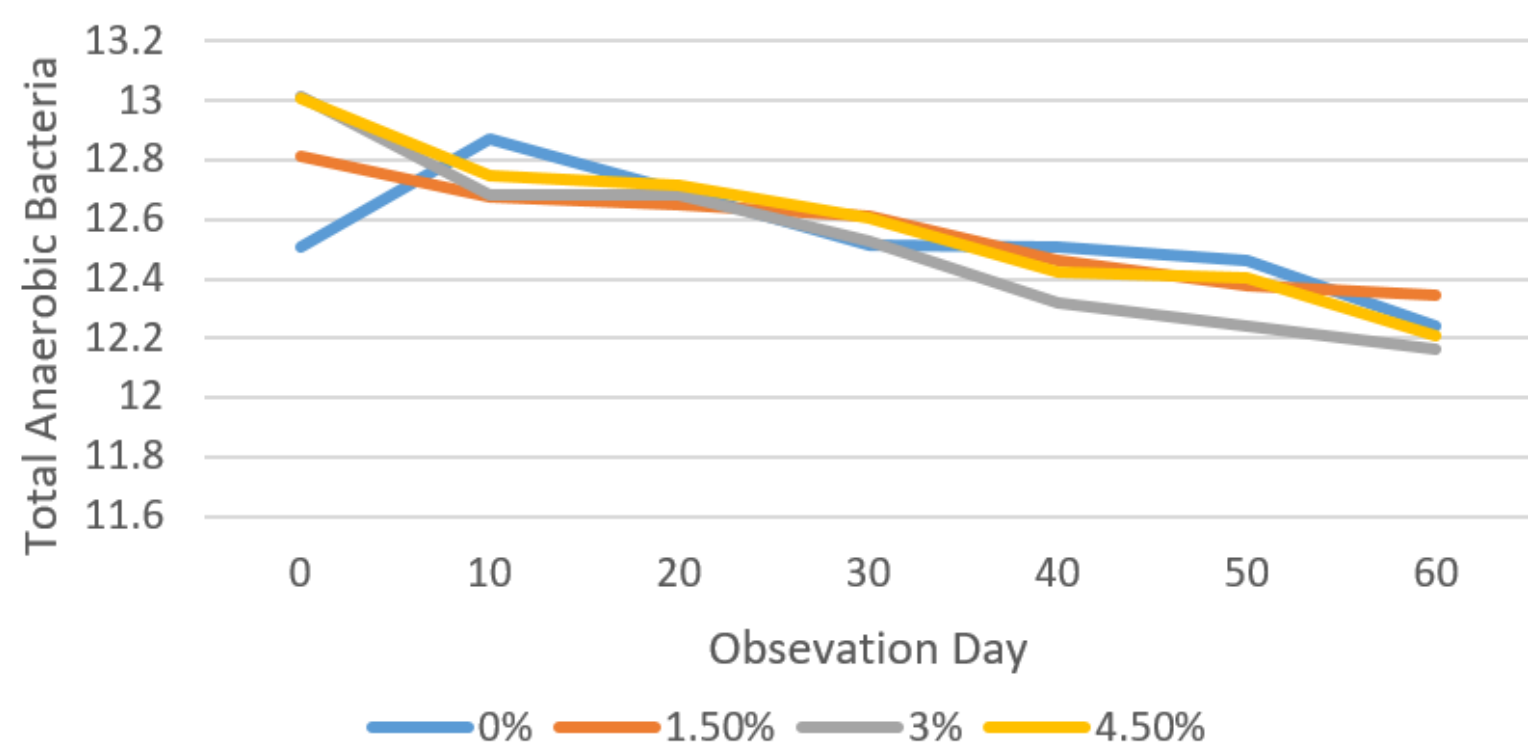

Figure 2. Total anaerobic bacteria 
Fig. 2 shows that at $0 \%(\mathrm{~T} 1)$, the number of anaerobic bacteria observed on day 10 increased then decreased until day 60. This condition explains that the lignite coal fermentation process with indigenous bacteria begins with increasing the number of anaerobic bacteria, reaching a certain amount, and producing biogas. This is in line with Fayyaz (2014) opinion, which states that the ratio of inoculum and substrate affects biogas production. The addition of $1.5 \%$ (T2), 3\% (T3), and $4.5 \%$ (T4) treatment resulted in the number of anaerobic bacteria with the same pattern, which decreased until the $60^{\text {th }}$ day of observation. However, at the $60^{\text {th }}$ day of observation, the addition of a starter with a treatment of $1.5 \%$ (T2) resulted in the highest amount of anaerobic bacteria. It is assumed that the addition of a starter with a $1.5 \%$ (T2) treatment is the amount of starter that is suitable with the available media, thus affecting the number of anaerobic bacteria that grow. This is in line with Hidayati (2018) opinion, which states that the growth of anaerobic bacteria is influenced by the number of inoculum and available media.

Effect of starter additions on lignite coal on biogas production

The research results on the effect of adding starters to lignite coal media on biogas production are presented in Fig. 3.

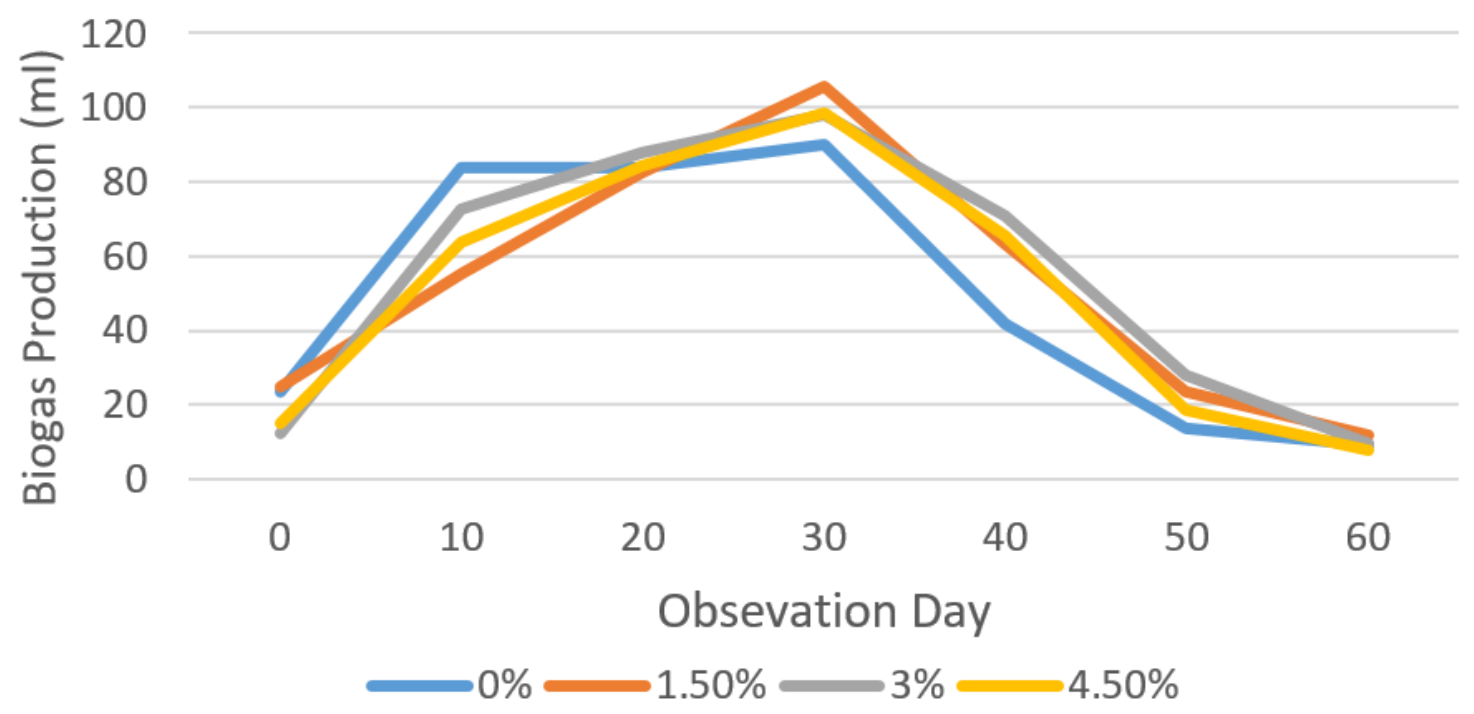

Figure 3. Biogas production

Figure 3 showed that the addition of a starter in the $1.5 \%$ (T2) produced the highest biogas production on the 30th-day observation, and subsequently, the biogas production decreased until the 60th-day observation. The biogas formation stage starts in the hydrolysis stage (0-7 days), followed by the acetogenic stage (7-14 days) and the metanogenic stage (14 - 30 days). The biogas formation depends on the organic material to be converted. Raja and Wazir (2017) reported that the average retention time for animal waste is $20-40$ days, and for organic waste, it is 60-90 days to become biogas.

\section{The effect of adding starters to lignite coal media on methane production}

The study results of the effect of starter additions to lignite coal media on the content of methane $\left(\mathrm{CH}_{4}\right)$ are presented in Fig. 4. 


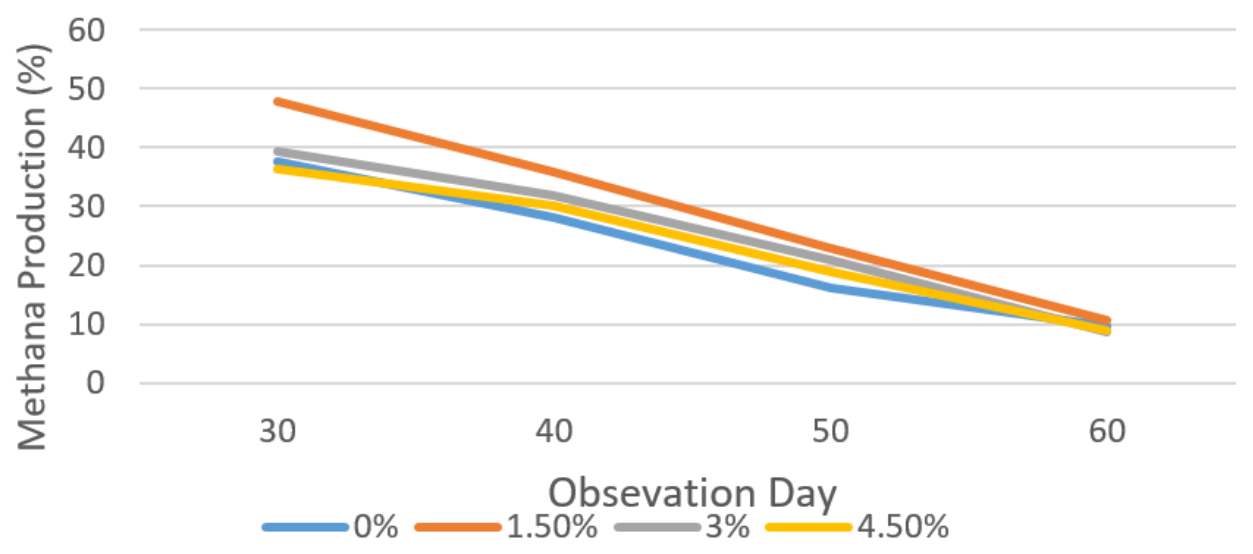

Figure 4. Methane production

Fig. 4 indicates that methane production begins to be detected at the $30^{\text {th }}$ day of observation. This is in accordance with the stages and patterns of biogas formation that methane will be formed at the end of the biogas formation stage. This is in line with the opinion of Akunna (2015), which state that the composition of biogas includes several gases, methane $\left(\mathrm{CH}_{4}\right)$, carbon dioxide $\left(\mathrm{CO}_{2}\right)$, hydrogen $\left(\mathrm{H}_{2}\right)$, nitrogen $\left(\mathrm{N}_{2}\right)$, oxygen $\left(\mathrm{O}_{2}\right)$, and hydrogen sulfide $\left(\mathrm{H}_{2} \mathrm{~S}\right)$, which the formation of each gas follows the pattern and stages in the process of forming biogas. The addition of starters from all doses of treatment showed the same pattern. However, the addition of a starter of $1.5 \%$ in $\mathrm{T} 2$ produced the highest methane $\left(\mathrm{CH}_{4}\right)$ yield. Presumably, the amount of starter added and the available media were balanced so that the fermentation process runs optimally. This is in line with Lawal's (2016) opinion, which states that methane production is determined by the ratio of inoculum and available media.

\section{CONCLUSIONS}

Potential bacteria in the feces of sheep from sheep fed Pennisetum purpureum and concentrate, in the crushed condition, produced $24 \mathrm{~mL}$ of biogas. The effect of adding a starter with a dose of $0.15 \%$ (T2) to lignite coal media produced anaerobic bacteria of $10^{12} \mathrm{CFU} / \mathrm{ml}$, biogas of 105.6 $\mathrm{mL}$, and methane of $47.84 \%$. Therefore, it can be concluded that the bacteria in sheep feces can be used as a starter for biogas formation in lignite coal media.

\section{REFERENCES}

Akunna, J. (2015). Anaerobic Treatment \#f Brewery Wastes. In Brewing Microbiology. Managing Microbes, Ensuring Quality and Valorising Waste. Woodhead Publishing

Ali, S. F., Mahmood, Q., Maroof Shah, M., Pervez, A., \& Ahmad Asad, S. (2014). Microbial ecology of anaerobic digesters: the key players of anaerobiosis. The Scientific World Journal, 2014, 1-21. https://doi.org/ $10.1155 / 2014 / 183752$

Beauchemin, K. A., Yang, W. Z., \& Rode, L. M. (2003). Effects of particle size of alfalfa-based dairy cow diets on chewing activity, ruminal fermentation, and milk production. Journal of Dairy Science, 86(2), 630643. https://doi.org/10.3168/jds.S00 22-0302(03)73641-8

Chen, T., Rodrigues, S., Golding, S. D., \& Rudolph, V. (2018). Improving coal bioavailability for biogenic methane production via hydrogen peroxide oxidation. International Journal of Coal Geology, 195, 402-414. https:// doi.org/10.1016/j.coal.2018.06.011

Hidayati, Y. A. K, Kurnani, T. B. A., Marlina, E. T., Rahmah, K. N., \& Harlia, E. (2018). The activation of 
microorganism inoculum from rumen of beef cattle. Journal of Physics: Conference Series, 1080, 012047. https://doi.org/10.1088/1742-6596/10 80/1/012047

Hidayati, Y. A. K., Marlina, E. T., Rahmah, K. N., \& Harlia, E. (2018). The Viability of anaerobic bacteria from beef cattle feces in liquid media. Journal of Powder Technology and Advanced Functional Materials, 1(1), 24-30. https://doi.org/10.29253/jptaf m.1.1.2018.4

Lawal, A. A., Dzivama, A. U., \& Wasinda, M. K. (2016). Effect of inoculum to substrate ratio on biogas \& amp;nbsp;production of sheep paunch manure. Research in Agricultural Engineering, 62(1), 8-14. https://doi. org/10.17221/30/2014-RAE

Lohani, S. P., \& Havukainen, J. (2018). Anaerobic Digestion: Factors Affecting Anaerobic Digestion Process. In S. J. Varjani (Ed.), Waste Bioremediation, Energy, Environment, dan Sustainability (pp. 343-359). Springer Nature Singapore Pte Ltd. https://doi.org/10.1007/978-981-107413-4_18

Marlina, E. (2009). Bioconversion of Livestock Industry Waste. UNPADPRESS.

Purnomo, A., Suprihatin, R. M., \&
Hasanudin, U. (2018). Biogas production from oil palm empty fruit bunches of post mushroom cultivation media. IOP Conference Series: Earth and Environmental Science, 141, 012024. https://doi.org/10.1088/17551315/141/1/012024

Raja, I. A., \& Wazir, S. (2017). Biogas production: the fundamental processes. Universal Journal of Engineering Science, 5(2), 29-37. https://doi.org/10.13189/ujes.2017.05 0202

Sahay, V. (2018). New Delhi, the fundamental relationship between coal rank and coal type. Journal of the Geological Society of India, 75.

Sidi, A. Z., \& Abdul, M. M. S. (2017). Effect of fermentation time, moisture content, and temperature on sorbitol production via solid state fermentation process. Journal of Chemical Engineering and Industrial Biotechnology, 1(1), 64-71. https:// doi.org/10.15282/jceib.v1i1.3812

Tanti, E., Ahmad, K. T. B., Hidayati, Y. A., Nur, R. K., \& Harlia, E. (2018). The potential of various livestock waste as sources of methanogenic bacteria. Journal of Powder Technology and Advanced Functional Materials, 1(1), 19-23. https://doi.org/10.29253/jptaf m.1.1.2018.3 